\title{
Thermocoagulation Treatment of a Patient with Obsessive Compulsive Disorder and Substance Use Disorder: Case Report
}

\section{Tratamento por termocoagulação de paciente com transtorno obsessivo-compulsivo e transtorno por uso de substâncias: Relato de caso}

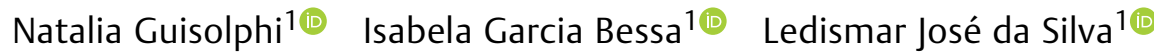

${ }^{1}$ School of Medicine, Pontifícia Universidade Católica de Goiás, Goiânia, GO, Brazil

Arq Bras Neurocir 2022;41(2):e212-e216.
Address for correspondence Ledismar José da Silva, MSc, School of Medicine, Pontifícia Universidade Católica de Goiás (PUC-Goiás), Avenida Universitária, 1440, Setor Universitário, 74605-010, Goiânia, GO, Brazil (e-mail: ledismarsilva@gmail.com).

\section{Abstract \\ Keywords \\ - stereotaxic technique \\ - substance-related disorder \\ - obsessive-compulsive disorder \\ - neurosurgery \\ - psychiatry \\ - quality of life}

\section{Resumo}

received

July 16,2021

accepted

July 30, 2021

published online

January 24, 2022
Obsessive compulsive disorder (OCD) is a possible cause associated with substance use disorder (SUD), a set of physical, psychological, behavioral, and cognitive phenomena related to the use of one or more chemical substances as a priority in a person's life that compromises quality of life. Since they can share the same neuronal network, this serves as a basis for neurosurgical procedures in cases refractory to conventional therapies. A 31-year-old male patient with a history of OCD and SUD refractory to conventional therapies underwent bilateral ablative stereotactic neurosurgery of the anterior limb of the internal capsule, the subgenual cingulate region, the nucleus accumbens, and the cingulate gyrus. Up to 33 months after the the procedure, the patient showed an absolute improvement in OCD and SUD and reported lack of withdrawal signs or symptoms and/or need to use drugs. In recent years, ablative neurosurgery has proven to be an alternative to OCD refractoriness, with long-term benefits. In the case analyzed, ablative stereotactic neurosurgery was effective in controlling both the signs and symptoms triggered by OCD, as well as those of anxiety and stress.

O transtorno obsessivo-compulsivo (TOC) é uma possível causa associada ao transtorno por uso de substâncias (TUS), um conjunto de fenômenos físicos, psicológicos, comportamentais e cognitivos relacionados ao uso de uma ou mais substâncias químicas como prioridade na vida de uma pessoa que compromete sua qualidade de vida. Como estes transtornos podem compartilhar a mesma rede neuronal, isto serve de base para procedimentos neurocirúrgicos em casos refratários às terapias

\footnotetext{
Janter 24.2022
}

DOI https://doi.org/ $10.1055 / \mathrm{s}-0041-1740166$ ISSN 0103-5355.

\footnotetext{
(c) 2022. Sociedade Brasileira de Neurocirurgia. All rights reserved. This is an open access article published by Thieme under the terms of the Creative Commons Attribution-NonDerivative-NonCommercial-License, permitting copying and reproduction so long as the original work is given appropriate credit. Contents may not be used for commercial purposes, or adapted, remixed, transformed or built upon. (https://creativecommons.org/ licenses/by-nc-nd/4.0/) Thieme Revinter Publicações Ltda., Rua do Matoso 170, Rio de Janeiro, RJ, CEP 20270-135, Brazil
} 


\author{
Palavras-chave \\ - técnica estereotáxica \\ - transtorno \\ relacionado ao uso de \\ substâncias \\ - transtorno obsessivo- \\ compulsivo \\ - neurocirurgia \\ - psiquiatria \\ - qualidade de vida
}

convencionais. Um paciente do sexo masculino de 31 anos com história de TOC e TUS refratários às terapias convencionais foi submetido a neurocirurgia estereotáxica ablativa bilateral do braço anterior da cápsula interna, da área subgenual, do núcleo accumbens e do giro do cíngulo. Até 33 meses após o procedimento, o paciente apresentou melhora absoluta do TOC e do TUS e relatou ausência de sinais ou sintomas de abstinência e/ou necessidade de uso de medicamentos. Nos últimos anos, a neurocirurgia ablativa tem se mostrado uma alternativa à refratariedade do TOC, com benefícios a longo prazo. No caso analisado, a neurocirurgia estereotáxica ablativa foi eficaz no controle tanto dos sinais e sintomas desencadeados pelo TOC como dos de ansiedade e estresse.

\section{Introduction}

Obsessive compulsive disorder (OCD) is characterized by obsession, defined as intrusive thoughts that may or may not be associated with compulsion, actions that alleviate the sensation of discomfort generated by them. ${ }^{1}$ Individuals affected by OCD experience reduced ability to voluntarily control or inhibit their own behavior and tend to act repeatedly. Compulsiveness has been shown to be one of the mechanisms capable of explaining the addiction to chemical substances, via negative reinforcement in the limbic system, cognitive and behavioral inflexibility, decreased prefrontal serotonergic control, and imbalanced frontostriatal and ventral habitual responses. ${ }^{2}$ Therefore, a dysfunction in the brain circuit may overlap the therapeutic targets of OCD and addiction.

Substance use disorder (SUD) is a complex condition that involves a set of physical, psychological, behavioral, and cognitive phenomena related to the use of one or more chemical substances as a priority in a person's life that compromises quality of life. The most severe form of SUD is often called addiction, when the users have difficulty keeping away from the substance even knowing that it will cause harm, affecting their quality of life, functionality, and interpersonal relationships. ${ }^{3}$ Over a quarter of the world population uses drugs and, of these, $\sim 35$ million people have a SUD. Alcohol, tobacco, cannabis, opioids, amphetamines, ecstasy, and cocaine are the most used substances worldwide. ${ }^{4}$ Drug use is still strongly associated with psychiatric comorbidities such as depression, anxiety, and OCD, mainly because they share some neuronal systems and similar risk factors. $^{4}$

Pharmacological therapy associated with psychotherapy is the first choice to treat psychiatric conditions. However, 30 to $40 \%$ of the individuals diagnosed with OCD are refractory to this treatment, and SUD also has a high refractoriness rate. ${ }^{5,6}$ Among the interventionist options, ablative stereotactic neurosurgery is a consolidated method in the treatment of psychiatric diseases. It is indicated for the treatment of patients who are refractory to conventional drug therapy and psychotherapy, for whom the benefits proposed are worth the risks of an invasive procedure. ${ }^{7}$ This type of surgical procedure has been proven to be effective in up to half of the cases. Additionally, the improvements last long after the surgery, giving hope to people affected by these disorders to have a better quality of life. ${ }^{8}$ Therefore, the present study aimed to report the case of a patient presenting with SUD and OCD who underwent thermocoagulation of the anterior limb of the internal capsule, the subgenual cingulate region, the nucleus accumbens, and the cingulate gyrus, bilaterally.

\section{Case Report}

\section{Ethics}

The present study was approved by the Ethics Committee on Human Research of the Universidade Federal de Goiás (no. 4.287.460/2020; CAAE: 33933520.5.3001.5078) and by the Ethics Committee on Human Research of the Pontifícia Universidade Católica de Goiás (no. 4.211.061/2020; CAAE: 33933520.5.0000.0037). The patient provided informed and written consent in accordance with the Declaration of Helsinki. ${ }^{9}$

\section{Patient History}

A single 31-year-old male agricultor sought care at our neurology service. He reported a history of drug addiction, anxiety, and OCD refractory to pharmacotherapy. He informed that SUD started when he was 15 years old, with alcohol consumption, and progressed to tobacco use at 17 , cocaine at 18 , cannabis at 21 , followed by crack abuse, including some episodes of overdose. As a result of drug abuse, he was voluntarily admitted in 2 different rehabilitation centers, staying there for 6 and 3 months, respectively. Withdrawal symptoms included irritability, anxiety, nervousness, aggression, insomnia, agitation, and hallucinations. The neuropsychological evaluation prior to the procedure revealed severe anxiety and near-exhaustion stress and confirmed OCD refractory to treatment (-Table $\mathbf{1}$ ).

\section{Surgical Procedure}

The patient underwent a stereotactic surgical procedure in August 2018. Thermocoagulation was performed using a 244-mm long electrode with a 4-mm length and $1.5-\mathrm{mm}$ diameter exposed tip at $70^{\circ} \mathrm{C}$ for 70 seconds guided by computed tomography (CT) and magnetic resonance 
Table 1 Neuropsychological assessment

\begin{tabular}{|c|c|c|c|}
\hline \multicolumn{4}{|c|}{ PRIOR TO THE PROCEDURE } \\
\hline Symptom & Scale & Score & Interpretation \\
\hline Depression & Beck Depression Inventory & 10 & Not depressed \\
\hline Anxiety & Beck Anxiety Inventory & 50 & Severe anxiety \\
\hline Stress & $\begin{array}{l}\text { Lipp's Stress Symptoms } \\
\text { Inventory for Adults }\end{array}$ & Phase 3 & Near-exhaustion \\
\hline $\begin{array}{l}\text { Obsessive compulsive } \\
\text { disorder }\end{array}$ & $\begin{array}{l}\text { Yale-Brown Obsessive-Compulsive } \\
\text { Scale }\end{array}$ & 36 & Refractory OCD \\
\hline \multicolumn{4}{|l|}{ AFTER THE PROCEDURE } \\
\hline Symptom & Scale & Score & Interpretation \\
\hline Depression & Beck Depression Inventory & 1 & Not depressed \\
\hline Anxiety & Beck Anxiety Inventory & 4 & Minimal level of anxiety \\
\hline Stress & $\begin{array}{l}\text { Lipp's Stress Symptoms } \\
\text { Inventory for Adults }\end{array}$ & $\begin{array}{l}\text { Did not reach } \\
\text { minimum score }\end{array}$ & Not stressed \\
\hline $\begin{array}{l}\text { Obsessive compulsive } \\
\text { disorder }\end{array}$ & Yale-Brown Obsessive-Compulsive Scale & 1 & $\begin{array}{l}\text { Responded to surgical treatment } \\
\text { (score improvement } \geq 35 \% \text { ) }\end{array}$ \\
\hline
\end{tabular}

Abbreviation: OCD, obsessive compulsive disorder.

imaging (MRI) fusion. Radiofrequency thermocoagulation aimed the following surgical targets: the anterior limb of the internal capsule, the subgenual cingulate region, the nucleus accumbens, and the cingulate gyrus, bilaterally. In the postoperative period, the patient was feverish until the $4^{\text {th }}$ day but had no signs of meningeal involvement. On the $5^{\text {th }}$ day, he was discharged from the hospital with a mild degree of mental confusion but no sensory or motor deficits.

\section{Results}

Thirty-three months after the surgical procedure, the patient reported continuous use of tobacco, but denied consumption of alcohol, cocaine, cannabis, and crack. He also affirmed that during this period he had no relapses or withdrawal signs or symptoms, and that his interpersonal relationships showed improvement, especially with his family. Currently, in addition to psychotherapy, he makes daily use of topiramate $25 \mathrm{mg}$, carbamazepine $200 \mathrm{mg}$, and chlorpromazine $25 \mathrm{mg}$. Postoperatively, the neuropsychological assessment indicated significant improvement in anxiety, stress, and OCD ( - Table $\mathbf{1}$ ), showing that the proposed procedure resulted in a good response.

\section{Discussion}

In recent years, neuroablation has emerged as an alternative in cases of OCD refractory to conventional therapy (YaleBrown Obsessive-Compulsive Scale [Y-BOCS] > 30). In 2015, a literature review that included 108 patients with refractory OCD who underwent anterior capsulotomy showed an average $51 \%$ decrease in the Y-BOCS score. ${ }^{10}$ In a 2019 metaanalysis, 367 individuals diagnosed with treatment-resistant OCD that underwent neuroablation and 314 that underwent deep brain stimulation (DBS) were assessed. The first group had a decrease in the Y-BOCS score of $50.4 \%$, whereas the second group had a $40.9 \%$ reduction postoperatively. ${ }^{11}$

A meta-analysis performed in 2020 analyzed the outcomes of 457 patients with severe and refractory OCD who underwent neuroablation and concluded that $55 \%$ of them achieved $\mathrm{a} \geq 35 \%$ reduction in the Y-BOCS. These results show that ablative neurosurgeries are safe and effective for many people with OCD refractory to conventional drug therapy and psychotherapy. ${ }^{6}$ In addition, comparing neuroablation with DBS, the literature suggests that the former is superior in individuals with refractory $O C D$, since it results in a higher decrease in the Y-BOCS score. ${ }^{10}$

On the one hand, in a literature review, the authors concluded that patients who underwent anterior capsulotomy were $9 \%$ more likely to go into remission than those treated with DBS, with no difference in the rates of adverse events between the 2 procedures. ${ }^{10}$ On the other hand, a meta-analytic study revealed that adverse events were higher in patients treated with DBS, with an incidence of $64.6 \%$ compared with $43.6 \%$ using neuroablation. ${ }^{11}$

The main advantages of neuroablation over DBS are its lower cost and absence of complications for maintenance such as programming and battery change. Furthermore, it is possible to access multiple anatomical targets in the same procedure. In the present case, neuroablation resulted in greater accessibility and comfort to the patient, given that he underwent a single surgical procedure with multiple targets. However, it has the disadvantage of generating irreversible injuries, which can result in long-term adverse events, unlike DBS, which allows adjustments in stimulation parameters and even turning the device off. ${ }^{8,10}$

In the reported case, the patient had a $97.3 \%$ reduction in the Y-BOCS score, an instrument used to assess the severity of OCD and its response to the proposed treatment. Patients who decrease their score by $\geq 35 \%$ are considered responsive 
to treatment. ${ }^{12,13}$ Thus, neuroablation was effective to control the signs and symptoms triggered by OCD of our patient, as well as those of anxiety and stress, in agreement with the literature consulted. ${ }^{8,10,11}$ Regarding SUD, after the neurosurgery, the patient stopped using all drugs, except tobacco. He has remained abstinent throughout the follow-up period of 30 months. It is worth mentioning that ablative surgeries to control SUD have an average remission rate of $58 \% 5$ years after the procedure. $^{14}$

The targets used in the present case play roles in the pathophysiology of both OCD and SUD, justifying the effective outcome for both. The main surgical targets with promising results in neurosurgery for the treatment of SUD are the nucleus accumbens, the anterior limb of the internal capsule, and the bed nucleus of the stria terminalis. ${ }^{14-17}$ The anterior cingulate cortex, the cingulate fibers, the anterior limb of the internal capsule, the ventral corticostriatal tracts at the head of caudate nucleus, and the frontotalamic fibers are the major targets to control OCD. 6,8

Only mild, transient, and controllable adverse events were observed in the present case. In a systematic review of 23 studies that included 487 patients who underwent neuroablation, most adverse events (88.4\%) were also classified as mild and transient. The most common adverse events were postoperative headache (14.9\%), cognitive deficits (9.1\%), and behavioral problems $(8.1 \%)$. Serious or permanent adverse events, not observed in our case, had and average incidence of $0.5 \%$, and the most common ones were personality changes $(2.3 \%)$, cerebral cysts or cerebral edema (1.5\%), behavioral disorders (1.3\%), and weight change $(1.0 \%)^{6}$

\section{Conclusion}

In line with the literature, the present results point to the benefits of neuroablation to our patient, given the significant improvement in OCD, SUD, anxiety, and stress scores. It is important to emphasize that the procedure did not cause significant adverse effects to the patient and did not prevent him from performing his usual daily activities. This demonstrates the possibility of improving the quality of life of individuals with similar conditions.

Conflict of Interests

The authors have no conflict of interests to declare.

\section{Acknowledgments}

The authors would like to thank Suzana Oellers for thoroughly reviewing and formatting the present manuscript and Dr João Batista Arruda for the valuable contribution to the surgical procedure.

\section{References}

1 Brock H, Hany M. Obsessive-compulsive disorder. In: StatPearls [Internet] Treasure Island, FL: StatPearls Publishing; 2021. Access on: May 25, 2021 at: https://www.ncbi.nlm.nih.gov/books/ NBK553162/

2 Figee M, Pattij T, Willuhn I, et al. Compulsivity in obsessivecompulsive disorder and addictions. Eur Neuropsychopharmacol 2016;26(05):856-868

3 Colon-Rivera $\mathrm{H}$, Balasanova $\mathrm{A}$. What is a substance use disorder? Washington, DC: American Psychiatric Association; 2017. Access on: May 25, 2021 at: https://www.psychiatry.org/patients-families/ addiction/what-is-addiction

4 United Nations. World Drug Report 2020. ViennaDivision for Policy Analysis and Public Affairs, United Nations Office on Drugs and Crime2020. Access on: May 25, 2021 at: https://wdr.unodc.org/wdr2020/field/WDR20_Booklet_2.pdf

5 Santos PLM, Curti RO, Silva LJ. Neurosurgical treatment for drug addiction: systematic review. Arq Bras Neurocir 2020;39(02): $116-124$

6 Lai Y, Wang T, Zhang C, et al. Effectiveness and safety of neuroablation for severe and treatment-resistant obsessive-compulsive disorder: a systematic review and meta-analysis. J Psychiatry Neurosci 2020;45(05):356-369

7 Nuttin B, Wu H, Mayberg H, et al. Consensus on guidelines for stereotactic neurosurgery for psychiatric disorders. J Neurol Neurosurg Psychiatry 2014;85(09):1003-1008

8 Balachander S, Arumugham SS, Srinivas D. Ablative neurosurgery and deep brain stimulation for obsessive-compulsive disorder. Indian J Psychiatry 2019;61(Suppl 1):S77-S84

9 World Medical Association. World Medical Association Declaration of Helsinki: ethical principles for medical research involving human subjects. JAMA 2013;310(20):2191-2194

10 Pepper J, Hariz M, Zrinzo L. Deep brain stimulation versus anterior capsulotomy for obsessive-compulsive disorder: a review of the literature. J Neurosurg 2015;122(05):1028-1037

11 Kumar KK, Appelboom G, Lamsam L, et al. Comparative effectiveness of neuroablation and deep brain stimulation for treatmentresistant obsessive-compulsive disorder: a meta-analytic study. J Neurol Neurosurg Psychiatry 2019;90(04):469-473

12 Pallanti S, Quercioli L. Treatment-refractory obsessive-compulsive disorder: methodological issues, operational definitions and therapeutic lines. Prog Neuropsychopharmacol Biol Psychiatry 2006;30(03):400-412

13 Goodman WK, Price LH, Rasmussen SA, et al. The Yale-Brown Obsessive Compulsive Scale. I. Development, use, and reliability. Arch Gen Psychiatry 1989;46(11):1006-1011

14 Hassan O, Phan S, Wiecks N, Joaquin C, Bondarenko V. Outcomes of deep brain stimulation surgery for substance use disorder: a systematic review. Neurosurg Rev. Updated October 2020. Access on: May 25, 2021 at: https://link.springer.com/article/10.1007\% 2Fs10143-020-01415-y

15 Zhu R, Zhang Y, Wang T, et al. Deep brain stimulation of nucleus accumbens with anterior capsulotomy for drug addiction: a case report. Stereotact Funct Neurosurg 2020;98(05):345-349

16 Gonçalves-Ferreira A, do Couto FS, Rainha Campos A, Lucas Neto LP, Gonçalves-Ferreira D, Teixeira J. Deep brain stimulation for refractory cocaine dependence. Biol Psychiatry 2016;79(11):e87-e89

17 Ma S, Zhang C, Yuan TF, et al. Neurosurgical treatment for addiction: lessons from an untold story in China and a path forward. Natl Sci Rev 2020;7(03):702-712. Doi: 10.1093/nsr/nwz207 